\author{
С.А. Макаров, О.М. Чекунова, О.П. Ковальчук, С.В. Селезньов
}

Харківський національний університет Повітряних Сил ім. І. Кожедуба, Харків

\title{
АНАЛІЗ ЕЛЕКТРОМАГНІТНОЇ СУМІСНОСТІ МІЖ РАДІОЕЛЕКТРОННИМИ ЗАСОБАМИ ПОВІТРЯНОЇ ТЕЛЕМЕТРІЇ ЗБРОЙНИХ СИЛ УКРАЇНИ ТА ЗАСОБАМИ ЗАГАЛЬНИХ КОРИСТУВАЧІВ У СМУЗІ ЧАСТОТ 1427-1532 МГЦ
}

У роботі проведено аналіз нормативно-правових документів у сфері використання радіочастотного спектру Украӥни. Для проведення оцінки й прогнозування електромагнітної сумісності РЕ3 стандарту LTE із засобами повітряної телеметрії Збройних Сил Украӥни та засобами циифрового звукового мовлення стандарту T-DAB проаналізовано діапазони робочих частот PE3 стандарту LTE з метою визначення смуг частот сумісного використання як загальними, так і спеціальними користувачами. У визначених смугах частот проаналізовано перелік військової техніки повітряної телеметрії Збройних Сил України, які використовують та потребують захисту від ненавмисних завад, створюваних випромінюванням РЕЗ стандарту LTE. Визначено необхідність досліджень удосконалення моделі множинної взаємодії РE3 стандарту LTE та засобів повітряної телеметрії Збройних Сил України і засобів циифрового звукового мовлення стандарту T-DАВ на міжсистемному рівні для визначення найгіриих умов їх взаємодіі.

Ключові слова: електромагнітна сумісність, радіоелектронні засоби, загальні користувачі, спеціальні користувачі, повітряна телеметрія, цичррове звукове мовлення, мережа мобільного зв'язку.

\section{Вступ}

Постановка проблеми. В Україні 3 кожним роком спостерігається тенденція перевантаження радіочастотного спектру внаслідок розвитку радіотехнологій, збільшення кількості радіозасобів як загального, так і спеціального призначення. Провайдери цифрового стільникового зв'язку, які використовують радіоелектронні засоби (РЕ3) технології LTE наполягають на державному рівні на необхідності перерозподілу радіочастотного спектру України.

На теперішній час в Україні користувачами досліджуваного діапазону частот 1427-1532 МГц є РE3 повітряної телеметрії Збройних Сил України (ЗСУ) та засоби цифрового звукового мовлення стандарту T-DAB за класифікацією Міжнародного союзу електрозв'язку (МСЕ). РЕЗ повітряної телеметрії відносяться до спеціальних користувачів (СК) та працюють на первинній основі. Відповідно [1] пріоритет у використанні частотного спектру в Україні надається СК. Тому постає актуальною задача забезпечення якісного функціонування РЕЗ СК у спільних та суміжних діапазонах радіочастот із РЕ3 загальних користувачів (ЗК). Для вирішення цієї задачі виникає необхідність застосовувати методи та методики прогнозування електромагнітної обстановки та аналізу електромагнітної сумісності (ЕМС).

Аналіз останніх досліджень і публікацій. Публікації [1-2; 20] є нормативно-правовими документами у сфері використання радіочастотного спектру України. Регламент радіозв'язку [20] є ос- новним документом Міжнародного союзу електрозв'язку (MCE), що визначає порядок використання будь-якого радіопристрою, який працює на території будь-якої з країн-членів МСЕ, умови використання радіочастот окремими радіослужбами в різних районах світу.

В роботах [3; 5-11] розглянуто проблему ЕМС в досліджуваних частотних діапазонах при впровадженні в Україні мереж стандарту LTE. У публікації [4] розглянуто шляхи підвищення ефективності використання радіочастотного ресурсу шляхом покращення частотної вибірковості радіолокаційних систем посадки, які використовуються в Повітряних Силах (ПС) ЗСУ.

У статті [12] проводиться дослідження ЕМС між РЕЗ повітряної рухомої та радіолокаційної служб з РЕЗ транкінгового зв'язку у смузі частот 136-174 МГц для їх сумісного беззавадового функціонування, що безпосередньо впливає на забезпечення належного рівня безпеки польотів. Обгрунтовується необхідність визначення можливості сумісного використання засобів повітряної рухомої та радіолокаційної служб ПС ЗСУ із РЕЗ транкінгового зв'язку іноземного виробництва.

У роботах [13-19] запропоновані методики аналізу ЕМС, що призначені для визначення можливого взаємного впливу групи РЕЗ радіозв'язку як фіксованої, так і рухомої радіослужб спеціального призначення. Запропоновані методики базуються на рекомендаціях Міжнародного союзу електрозв'язку (MCE). Особливістю розроблених методик $\epsilon$ їх оріє- 
нтація на практичну реалізацію для отримання комплексного вирішення задачі аналізу ЕМС засобів радіозв'язку.

Аналіз останніх публікацій дозволяє стверджувати про актуальність теми, яка обумовлена швидкоплинним перевантаженням радіочастотного спектру України, як наслідок, необхідністю визначення умов сумісного використання РЕЗ ЗК і СК на основі аналізу їх ЕMC.

Мета статті. Проаналізувати та визначити потенційно несумісних типів РЕЗ повітряної телеметpiï ЗСУ із засобами цифрового звукового мовлення стандарту T-DAB і мереж мобільного зв'язку стандарту LTE у смузі частот 1427 - 1532 МГц.

\section{Виклад основного матеріалу}

Стрімкий розвиток та впровадження систем мобільного зв'язку четвертого покоління, яке пов'язане з використанням радіочастотного спектру України, може привести до ненавмисного впливу PE3 стандарту LTE на засоби повітряної телеметрії, що знаходяться на озброєнні ПС ЗСУ та засоби цифрового звукового мовлення стандарту T-DAB цивільного призначення [1]. Розглянемо смуги радіочастот, які визначені нормативно-правовими документами для впровадження мереж мобільного зв'язку стандарту LTE в Україні.

Для впровадження системи мобільного зв'язку четвертого покоління на всесвітньому рівні визначено частотні діапазони, які наведені у табл. 1 [2].

Таблиця 1

Діапазони робочих частот PE3 стандарту LTE

\begin{tabular}{|c|c|c|l|}
\hline $\begin{array}{c}\text { Номер } \\
\text { діап. } \\
\text { (band) }\end{array}$ & $\begin{array}{c}\text { Діапазон } \\
\text { робочих частот } \\
\text { UL, МГц MC }\end{array}$ & $\begin{array}{c}\text { Діапазон } \\
\text { робочих частот } \\
\text { DL, МГц БС }\end{array}$ & Режим \\
\hline 1 & $1920-1980$ & $2110-2170$ & FDD \\
\hline 2 & $1850-1910$ & $1930-1990$ & FDD \\
\hline 3 & $1710-1785$ & $1805-1880$ & FDD \\
\hline 4 & $1710-1755$ & $2110-2155$ & FDD \\
\hline 5 & $824-849$ & $869-894$ & FDD \\
\hline 6 & $830-840$ & $875-885$ & FDD \\
\hline 7 & $2500-2570$ & $2620-2690$ & FDD \\
\hline 8 & $880-915$ & $925-960$ & FDD \\
\hline 9 & $1749,9-1784,9$ & $1844,9-1879,9$ & FDD \\
\hline 10 & $1710-1770$ & $2110-2170$ & FDD \\
\hline $\mathbf{1 1}$ & $\mathbf{1 4 2 7 , 9 - 1 4 4 7 , 9}$ & $\mathbf{1 4 7 5 , 9 - 1 4 9 5 , 9}$ & FDD \\
\hline 12 & $699-716$ & $729-746$ & FDD \\
\hline 13 & $777-787$ & $746-756$ & FDD \\
\hline 14 & $788-798$ & $758-768$ & FDD \\
\hline 15 & Резерв & Резерв & FDD \\
\hline 16 & Резерв & Резерв & FDD \\
\hline 17 & $704-716$ & $734-746$ & FDD \\
\hline 18 & $815-830$ & $860-875$ & FDD \\
\hline 19 & $830-845$ & $875-890$ & FDD \\
\hline & & & \\
\hline
\end{tabular}

Закінчення табл. 1

\begin{tabular}{|c|c|c|c|}
\hline $\begin{array}{l}\text { Номер } \\
\text { діап. } \\
\text { (band) }\end{array}$ & $\begin{array}{c}\text { Діапазон } \\
\text { робочих частот } \\
\text { UL, МГц МС }\end{array}$ & $\begin{array}{c}\text { Діапазон } \\
\text { робочих частот } \\
\text { DL, МГц БС }\end{array}$ & Режим \\
\hline 20 & $832-862$ & $791-821$ & FDD \\
\hline 21 & $\begin{array}{c}1447,9- \\
1462,9\end{array}$ & $\begin{array}{c}1495,9- \\
1510,9\end{array}$ & FDD \\
\hline 22 & $3410-3490$ & $3510-3590$ & FDD \\
\hline 23 & $2000-2020$ & $2180-2200$ & FDD \\
\hline 24 & $1626,5-1660,5$ & $1525-1559$ & FDD \\
\hline 25 & $1850-1915$ & $1930-1995$ & FDD \\
\hline 26 & $814-849$ & $859-894$ & FDD \\
\hline 27 & $807-824$ & $852-869$ & FDD \\
\hline 28 & $703-748$ & $758-803$ & FDD \\
\hline 29 & Не визначено & $717-728$ & FDD \\
\hline 30 & $2305-2315$ & $2350-2360$ & FDD \\
\hline 31 & $452,5-457,5$ & $462,5-467,5$ & FDD \\
\hline 32 & Не визначено & $1452-1496$ & FDD \\
\hline 33 & $1900-1920$ & $1900-1920$ & TDD \\
\hline 34 & $2010-2025$ & $2010-2025$ & TDD \\
\hline 35 & $1850-1910$ & $1850-1910$ & TDD \\
\hline 36 & $1930-1990$ & $1930-1990$ & TDD \\
\hline 37 & $1910-1930$ & $1910-1930$ & TDD \\
\hline 38 & $2570-2620$ & $2570-2620$ & TDD \\
\hline 39 & $1880-1920$ & $1880-1920$ & TDD \\
\hline 40 & $2300-2400$ & $2300-2400$ & TDD \\
\hline 41 & $2496-2690$ & $2496-2690$ & TDD \\
\hline 42 & $3400-3600$ & $3400-3600$ & TDD \\
\hline 43 & $3600-3800$ & $3600-3800$ & TDD \\
\hline 44 & $703-803$ & $703-803$ & TDD \\
\hline 45 & $1447-1467$ & $1447-1467$ & TDD \\
\hline 46 & $5150-5925$ & $5150-5925$ & TDD \\
\hline 47 & $5855-5925$ & $5855-5925$ & TDD \\
\hline 48 & $3550-3700$ & $3550-3700$ & TDD \\
\hline 49 & $3550-3700$ & $3550-3700$ & TDD \\
\hline 50 & $1432-1517$ & $1432-1517$ & TDD \\
\hline 51 & $1427-1432$ & $1427-1432$ & TDD \\
\hline 52 & $3300-3400$ & $3300-3400$ & TDD \\
\hline 65 & $1920-2010$ & $2110-2200$ & FDD \\
\hline 66 & $1710-1780$ & $2110-2200$ & FDD \\
\hline 67 & Не визначено & $738-758$ & FDD \\
\hline 68 & $698-728$ & $753-783$ & FDD \\
\hline 69 & Не визначено & $2570-2620$ & FDD \\
\hline 70 & $1695-1710$ & $1995-2020$ & FDD \\
\hline 71 & $663-698$ & $617-652$ & FDD \\
\hline 72 & $451-456$ & $461-466$ & FDD \\
\hline 73 & $450-455$ & $460-465$ & FDD \\
\hline 74 & $1427-1470$ & $1475-1518$ & FDD \\
\hline 75 & Не визначено & $1432-1517$ & FDD \\
\hline 76 & Не визначено & $1427-1432$ & FDD \\
\hline 85 & $698-716$ & $728-746$ & FDD \\
\hline 87 & $410-415$ & $420-425$ & FDD \\
\hline 88 & $412-417$ & $422-427$ & FDD \\
\hline
\end{tabular}

Джерело: [2]. 
Застосування засобів повітряної телеметрії, що знаходяться на озброєнні ЗСУ, обмежує розвиток та впровадження сучасних новітніх технологій, спрямованих на розвиток національної інформаційної інфраструктури. У розвинених державах спостерігається тенденція сумісного використання радіочастотного спектру, як ЗК, так і СК.

Розподіл смуг радіочастотного спектру між радіоелектронними засобами на Україні регламентований Національною таблицею розподілу смуг радіочастот України [1]. Радіоелектронні засоби поділяються на РЕЗ ЗК та РЕЗ СК. При цьому смуги, що використовуються сумісно, передбачають надання пріоритетності радіослужбам (на первинній та вторинній основі).

Радіослужба, розподіл радіочастот якої зроблено на первинній основі, може вимагати захисту від негативного впливу випромінювання РЕЗ такої ж та інших радіослужб. Радіослужба, розподіл радіочастот якої зроблено на вторинній основі:

- може вимагати захисту від негативного впливу випромінювання РЕ3 такої ж та інших радіослужб, яким ці частоти розподілені на вторинній основі;

- не повинна створювати завад та вимагати захисту від негативного впливу випромінювання PE3 радіослужб, яким розподіл цих частот зроблений на первинній основі.

Застосування РЕЗ СК у смугах радіочастот загального користування здійснюється, у разі необхідності, за узгодженням відповідних частотних присвоєнь з Національною комісією, що здійснює регулювання у сфері зв'язку та інформатизації (НКРЗІ).

Відповідно до примітки У093 Національної таблиці розподілу смуг радіочастот України (НТРСРЧ) смуги частот розподілені між радіослужбами згідно табл. 2.

Для потреб СК відповідно примітки У093 смуга радіочастот 1525 - 1530 МГц додатково розподілена у рухомій супутниковій службі.

У зазначених смугах РЕЗ ЗК не повинні створювати завад роботі РЕЗ СК. РЕЗ СК не повинні створювати завад роботі РЕЗ ЗК, якщо інші умови не визначені у разі погодження з Генеральним штабом ЗСУ.

Таблиця 2

Витяг з Національної таблиці розподілу смуг радіочастот України

\begin{tabular}{|c|c|}
\hline $\begin{array}{c}\text { Смуга } \\
\text { радіочастот }\end{array}$ & $\begin{array}{c}\text { Застосовувана } \\
\text { радіослужба }\end{array}$ \\
\hline $1427-1429$ МГц & $\begin{array}{l}\text { СЛУЖБА КОСМІЧНОЇ } \\
\text { ЕКСПЛУАТАЦЇ̈ } \\
\text { (ЗемЛя -Космос), } \\
\text { РУХОМА, за винятком пові- } \\
\text { тряної рухомої } \\
\text { ФІКСОВАНА; }\end{array}$ \\
\hline
\end{tabular}

Закінчення табл. 2

\begin{tabular}{|c|c|}
\hline $\begin{array}{c}\text { Смуга } \\
\text { радіочастот }\end{array}$ & $\begin{array}{c}\text { Застосовувана } \\
\text { радіослужба }\end{array}$ \\
\hline $1429-1452$ МГц & $\begin{array}{l}\text { ФІКСОВАНА РУХОМА, за } \\
\text { винятком повітряної рухомої } \\
\text { ПОВІТРЯНА РУХОМА }\end{array}$ \\
\hline $1452-1492$ МГц & $\begin{array}{l}\text { ФІКСОВАНА РУХОМА, за } \\
\text { винятком повітряної рухомої } \\
\text { РАДІОМОВНА } \\
\text { СУПУТНИКОВА } \\
\text { ПОВІТРЯНА РУХОМА } \\
\end{array}$ \\
\hline $1492-1518$ МГц & $\begin{array}{l}\text { ФІКСОВАНА РУХОМА, за } \\
\text { винятком повітряної рухомої } \\
\text { ПОВІТРЯНА РУХОМА }\end{array}$ \\
\hline $1518-1525$ МГц & $\begin{array}{l}\text { ФІКСОВАНА РУХОМА, за } \\
\text { винятком повітряної рухомої } \\
\text { РУХОМА СУПУТНИКОВА } \\
\text { (космос - Земля) } \\
\text { ПОВІТРЯНА РУХОМА } \\
\end{array}$ \\
\hline $1525-1530$ МГц & $\begin{array}{l}\text { СЛУЖБА КОСМІЧНОЇ } \\
\text { ЕКСПЛУАТАЦІЇ (космос - } \\
\text { Земля) ФІКСОВАНА } \\
\text { РУХОМА СУПУТНИКОВА } \\
\text { (космос - Земля) Супутникова } \\
\text { служба дослідження Землі } \\
\text { Рухома, за винятком повітря- } \\
\text { ної рухомої ПОВІТРЯНА } \\
\text { РУХОМА }\end{array}$ \\
\hline $1530-1535$ МГц & $\begin{array}{lr}\text { ПОВІТРЯНА } & \text { РУХОМА } \\
\text { СЛУЖБА } & \text { КОСМІЧНӦ } \\
\text { ЕКСПЛУАТАЦІІ } & \text { (космос - } \\
\text { ЗемЛя) } & \text { РУХОМА } \\
\text { СУПУТНИКОВА } & \text { (космос - } \\
\text { ЗемЛя) Супутникова служба } \\
\text { дослідження Землі Фіксова- } \\
\text { на Рухома, за винятком по- } \\
\text { вітряної рухомої }\end{array}$ \\
\hline
\end{tabular}

Джерело: [1].

Особливості застосування смуги радіочастот 1427 - 1532 МГц, яка використовується засобами повітряної телеметрії, визначені Постановою Кабінету Міністрів України від 9 червня 2006 р. № 815 зі змінами № 1263 від 16.12.2020 "Про затвердження Плану використання радіочастотного ресурсу України” (далі - План використання РЧР України), де конкретизовані (уточнені) умови використання смуг, номіналів частот для впровадження мереж РЕЗ за стандартом четвертого покоління LTE.

На теперішній час, діючими радіотехнологіями в Україні є [2]:

- у смузі радіочастот від 1427 - 1451,5 МГц, 1477 - 1497,5 МГц: широкосмуговий радіодоступ; ФІКСОВАНА (пункт 24 Розділу I Плану використання РЧР України);

- у смузі радіочастот від 1525 - 1559 МГц: безпроводове забезпечення заходів загальнодержав- 
ного або міжнародного рівня; ФІКСОВАНА СУПУТНИКОВА, РУХОМА СУПУТНИКОВА (пункт 52.1 Розділу I Плану використання РЧР України).

Радіотехнології, які застосовуються СК:

- у смузі радіочастот від 1525 - 1559 МГц: ультракороткохвильовий радіозв'язок; ПОВІТРЯНА РУХОМА (пункт 55 Розділу І Плану використання РЧР України);

- у смузі радіочастот від 400 - 1433 МГц: радіолокація; РАДІОЛОКАЦІЙНА (пункт 57 Розділу I Плану використання РЧР України);

- у смузі радіочастот від 1497,5 - 1710 МГц: радіорелейний зв'язок; РУХОМА (пункт 61 Розділу I Плану використання РЧР України);

- у смузі радіочастот від 1500 - 15000 МГц: супутниковий радіозв'язок; РУХОМА СУПУТНИКОВА (пункт 64 Розділу I Плану використання РЧР України).

Перспективними для впровадження радіотехнологіями, які плануються для застосування ЗК є:

- у смугах радіочастот від 1452 - 1479,5 МГц цифрове наземне радіомовлення стандарту T-DAB; РАДІОМОВНА (видача ліцензій на користування радіочастотним ресурсом із використанням зазначеної радіотехнології разом із можливістю використання інших радіотехнологій у конкретних смугах у межах зазначених смуг радіочастот проводиться на конкурсних або тендерних засадах за умови їх вивільнення існуючими користувачами та за результатами відповідних досліджень (пункт 3 Розділу II Плану використання РЧР України) [2].

Аналіз смуги радіочастот 1427-1532 МГц, визначеної для впровадження мереж рухомого (мобільного) зв'язку технології LTE, показує, що він вже використовується РЕЗ повітряної телеметрії ЗСУ.

Основна частка радіочастотного спектру для надання послуг операторами телекомунікацій за стандартом LTE (band 11, band 21, band 24, band 32, band 45 , band 50, band 51, band 74, band 75 , band 76 таблиці 1) на даний час використовується засобами повітряної телеметрії, що потребує проведення теоретичних та практичних досліджень для визначення умов ЕМС з РЕЗ СК для забезпечення їх сумісного беззавадового функціонування.

На підставі приміток 5.341А та 5.342 Частини 1 Регламенту радіозв'язку Міжнародного союзу електрозв'язку ITU RR-2020 [20] стосовно використання радіочастотного спектру мереж технології LTE визначено перелік рухомих служб, які можуть використовувати визначену смугу та потребують дослідження ї ЕMC з РЕ3 систем мобільного зв'язку технології LTE. Витяг 3 примітки 5.341A RR-2020 [20]: В Районе 1 полосы частот 1427-1452 МГц и 1492-1518 МГц определены для использования администрациями, желающими внедрить Междуна- родную подвижную электросвязь (IMT) в соответствии с Резолюцией 223 (Пересм. ВКР-19). Данное определение не препятствует использованию этих полос частот каким-либо другим применением служб, которым они распределены, и не устанавливает приоритета в Регламенте радиосвязи. Использование станций IMT осуществляется при условии получения согласия в соответствии с п. 9.21 в отношении воздушной подвижной службы, используемой для воздушной телеметрии в соответствии п. 5.342 (ВКР-15).

Витяг з примітки 5.342 RR-2020 [20]: Дополнительное распределение: в Армении, Азербайджане, Беларуси, Российской Федерации, Узбекистане, Кыргызстане и Украине полоса частот 14291535 МГц распределена также воздушной подвижной службе на первичной основе исключительно для воздушной телеметрии в пределах национальной территории (ВКР-15).

У смузі радіочастот від 1427 МГц до 1532 МГц працюють такі РЕЗ повітряної телеметрії:

- наземні радіолокаційні запитувачі типу 71Е6, 73Е6, 76Е6, 1Л22, 1Л23, 1Л24;

- літаковий радіолокаційний запитувач типу 6231

- літакові радіолокаційні відповідачі типу $6201,6202$.

\section{Висновки}

В статті на основі аналізу нормативноправових документів у сфері використання радіочастотного спектру України та аналізу діапазонів робочих частот засобів повітряної телеметрії ЗСУ і PE3 мобільного зв'язку стандарту LTE визначено потенційно несумісні типи РЕЗ повітряної телеметpiï ЗСУ із засобами цифрового звукового мовлення стандарту T-DAB і мереж мобільного зв'язку стандарту LTE у смузі частот 1427 - 1532 МГц, а саме:

- наземні радіолокаційні запитувачі типу 71E6, 73Е6, 76Е6, 1Л22, 1Л23, 1Л24;

- літаковий радіолокаційний запитувач типу 6231

- літакові радіолокаційні відповідачі типу 6201, 6202 і базові станції та абонентські термінали мереж мобільного зв'язку стандарту LTE (band 74).

Визначення та прогнозування умов ЕMC між PE3 повітряної телеметрії ЗСУ та засобами цифрового звукового мовлення стандарту T-DAB і мережами мобільного зв'язку за технологією LTE у смузі частот 1427 - 1532 МГц РЕЗ при їх впровадженні в Україні у спільних смугах частот потребує у подальшому удосконалення моделі множинної взаємодії PE3 LTE та PE3 повітряної телеметрії ЗСУ, а також засобами цифрового звукового мовлення стандарту T-DAB на міжсистемному рівні для визначення найгірших умов їх взаємодії відповідно. 


\section{Список літератури}

1. Про затвердження Національної таблиці розподілу смуг радіочастот України : Постанова Кабінету Міністрів України від 15 груд. 2005 р. № 1208 (із змінами № 15 від 15.01.2020). URL: http://zakon3.rada.gov.ua/laws/show/1208-2005-п (дата звернення 12.08.2021).

2. Про затвердження Плану використання радіочастотного ресурсу України : Постанова Кабінету Міністрів України від 09 черв. 2006 р. № 815 (із змінами № 1263 від 16.12.2020). URL: http://zakon2.rada.gov.ua/laws/show/815-2006-п (дата звернення 11.08.2021).

3. Макаров С. А., Поздняк В. П., Дукін Г. Ю. Аналіз електромагнітної сумісності радіоелектронних засобів в умовах впровадження в Україні цифрового мовлення. Системи обробки інформаиії. 2006. № 3(52). С. 89-93.

4. Макаров С. А. Підвищення ефективності використання радіочастотного ресурсу шляхом покращення частотної вибірковості радіолокаційних систем посадки. Системи обробки інформації. 2012. № 9(107). C. 46-49. URL: http://www.hups.mil.gov.ua/periodic-app/journal/soi/2012/9 (дата звернення 12.08.2021).

5. Макаров С. А, Поздняк В. П., Висоцький О. В., Лєбєдєв В. О. Методи аналізу міжсистемної електромагнітної сумісності на перехідний період конверсії для розвитку мереж UMTS : сб. научн. тр. перв. междунар. научно-технич. конф. Харьков : ХНУРЕ, 2015. С. 106-108.

6. Макаров С. А., Лєбєдєв В. О. Аналіз забезпечення електромагнітної сумісності новітніх засобів стільникового зв'язку та радіотехнічних систем забезпечення польотів державної авіації. Новітні технології - для захисту повітряного простору : зб. тез доп. XII наук. конф. Харківського національного університету Повітряних Сил ім. I. Кожедуба. Харків : ХУПС ім. І. Кожедуба, 2016. С. 200.

7. Макаров С. А., Лєбєдєв В. О., Сокол О. О. Проблема електромагнітної сумісності при впровадженні системи рухомого зв'язку четвертого покоління в смузі частот 790 - 862 МГц. Новітні технології - для захисту повітряного проcmopy : зб. тез доп. ХІІІ наук. конф. Харківського національного університету Повітряних Сил ім. І. Кожедуба. Харків : ХНУПС ім. I. Кожедуба, 2017. C. 246-247. URL: http://www.hups.mil.gov.ua/nauka/konferencii-kursantiv-tastudentiv/trinadcyata-naukova-konferenciya-24-25-travnya-2017-roku (дата звернення 12.08.2021).

8. Макаров С. А., Лєбєдєв В. О., Висоцький О. В. Проблема електромагнітної сумісності при впровадженні в Україні мереж радіотехнології четвертого покоління LTE 800. Проблемы электромагнитной совместимости перспективных беспроводных сетей святи (ЭМС-2017) : сб. науч. тр. втор. междун. научно-технич. конф. Харьков: ХНУРЕ, 2017. C. 31-34.

9. Лєбєдєв В. О., Костенко І. Л., Поздняк В. П., Павліченко О. А. Проблема електромагнітної сумісності при впровадженні в Україні мереж радіотехнології LTE у смугах частот $880 \ldots 915$ МГц та $925 \ldots 960$ МГц. Проблемы электромагнитной совместимости перспективных беспроводных сетей связи (ЭМС-2018) : сб. науч. тр. втор. междун. научно-технич. конф. Харьков: ХНУРЕ, 2018. С. 5-8. URL: https://nure.ua/wp-content/uploads/workshop/ems2018.pdf (дата звернення 12.08.2021).

10. Лєбєдєв В. О., Макаров С. А., Висоцький О. В. Аналіз електромагнітної сумісності смуги частот 790-862 МГц на території України для впровадження мережі мобільного зв'язку за технологією LTE. Радіотехніка. 2017. № 3(190). C. 22-25. URL: http://rt.nure.ua/article/view/179988 (дата звернення 12.08.2021).

11. Макаров С. А., Московченко І. В., Лєбєдєв В. О., Павліченко О. А. Дослідження умов електромагнітної сумісності радіоелектронних засобів повітряної рухомої й радіолокаційної служб та засобів транкінгового зв'язку у смузі частот 136...174 МГц. Наука і техніка Повітряних Сил Збройних Сил Украӥни. 2017. № 4(29). С. 48-53. https://doi.org/ 10.30748/nitps.2017.29.06.

12. Степанов Г. С., Лєбєдєв В. О., Павленко М. А. Удосконалення методу аналізу міжсистемної електромагнітної сумісності угрупування військової техніки повітряної радіонавігаційної служби та радіоелектронних засобів мережі рухомого зв'язку за технологією LTE на основі декомпозиції та суперпозиції частотного спектру випромінюваного широкосмугового складового сигналу. Труди університету. 2018. № 5(150). С. 56-67.

13. Коваленко І. Г. Методика аналізу об'єктової електромагнітної сумісності засобів зв'язку. Збірник наукових праць ВІТІ НТУУ „КПІ”. 2013. № 2. С. 28-33.

14. Коваленко І. Г. Методика аналізу електромагнітної сумісності засобів радіозв'язку фіксованої радіослужби спеціального призначення. Збірник наукових пращь ВITI НТУУ „КПI”. 2014. № 1. C. 21-29. URL: http://www.viti.edu.ua/ files/zbk/2014/zb_1501.pdf (дата звернення 12.08.2021).

15. Коваленко I. Г. Методика аналізу електромагнітної сумісності засобів радіозв'язку рухомої радіослужби спеціального призначення. Збірник наукових пращь ВITI НТУУ „КПI”. 2015. № 1. С. 35-41. URL: http://www.viti.edu.ua/ files/zbk/2015/2_1_2015.pdf (дата звернення 12.08.2021).

16. Коваленко І. Г., Бригадир С. П., Мазниченко Ю. А. Методика аналізу електромагнітної сумісності засобів радіозв’язку спеціального призначення. Збірник наукових праць ВITI НТУУ „КПI”. 2016. № 1. C. 71-80. URL: http://www.viti.edu.ua/files/zbk/2016/3_1_2016.pdf.

17. Коваленко І. Г., Малих В. В., Макарчук В. І. Загальна методика та алгоритм розрахунку електромагнітної сумісності радіоелектронних засобів. Збірник наукових пращъ ВITI НТУУ „КПI”. 2020. № 2. C. 17-27. URL: http://www.viti.edu.ua/files/zbk/2020/2_2_2020.pdf (дата звернення 12.08.2021).

18. Бузов А. Л. Управление радиочастотным спектром и электромагнитная совместимость радиосистем : монография / под редакцией М. А. Быховского. Москва : Эко-Трендз, 2006. 376 с.

19. Recommendation ITU-R P.341-5. The concept of transmission loss for radio links. URL: https://www.itu.int/dms_pub/itu-r/md/12/sg03/rp/R12-SG03-RP-1002!!MSW-E.docx (дата звернення 12.08.2021).

20. Регламент радиосвязи. URL: https://docs.cntd.ru/document/565737147 (дата звернення 12.08.2021). 
Відомості про авторів:

Макаров Сергій Анатолійович кандидат технічних наук доцент начальник факультету Харківського національного університету Повітряних Сил ім. І. Кожедуба, Харків, Україна

https://orcid.org/0000-0002-4708-5449

\section{Чекунова Оксана Миколаївна} кандидат технічних наук старший науковий співробітник Харківського національного університету Повітряних Сил ім. І. Кожедуба, Харків, Україна http://orcid.org/0000-0001-9613-7244

\section{Ковальчук Олександр Петрович} заступник начальника факультету Харківського національного університету Повітряних Сил ім. І. Кожедуба, Харків, Україна http://orcid.org/0000-0003-1860-1720

\section{Селезньов Сергій Володимирович} кандидат технічних наук начальник науково-дослідної лабораторії Харківського національного університету Повітряних Сил ім. І. Кожедуба,

Харків, Україна http://orcid.org/0000-0003-1910-3555
Information about the authors:

\section{Sergij Makarov}

Candidate of Technical Sciences Associate Professor

Head of the Faculty of Ivan Kozhedub Kharkiv

National Air Force University,

Kharkiv, Ukraine

https://orcid.org/0000-0002-4708-5449

\section{Oksana Chekunova}

Candidate of Technical Sciences

Senior Researcher of Ivan Kozhedub Kharkiv

National Air Force University,

Kharkiv, Ukraine

http://orcid.org/0000-0001-9613-7244

\author{
Alexander Kovalchuk \\ Deputy Head of the Faculty \\ of Ivan Kozhedub Kharkiv National Air Force \\ University, \\ Kharkiv, Ukraine \\ http://orcid.org/0000-0003-1860-1720 \\ Serhii Seleznov \\ Candidate of Technical Sciences \\ Chief of Research Laboratory of Ivan \\ Kozhedub Kharkiv National Air Force \\ University, \\ Kharkiv, Ukraine \\ http://orcid.org/0000-0003-1910-3555
}

\title{
АНАЛИЗ ЭЛЕКТРОМАГНИТНОЙ СОВМЕСТИМОСТИ МЕЖДУ РАДИЭЛЕКТРОННЫМИ СРЕДСТВАМИ ВОЗДУШНОЙ ТЕЛЕМЕТРИИ ВООРУЖЕННЫХ СИЛ УКРАИНЫ И СРЕДСТВАМИ ОБЩИХ ПОЛЬЗОВАТЕЛЕЙ В ПОЛОСЕ ЧАСТОТ 1427-1532 МГЦ
}

\author{
С.А. Макаров, О.Н. Чекунова, О.П. Ковальчук, С.В. Селезнев
}

В работе проведен анализ нормативно-правовых документов в сфере использования радиочастотного спектра Украины. Для проведения оиенки и прогнозирования электромагнитной совместимости РЭС стандарта LTЕ со средствами воздушной телеметрии Вооруженных Сил Украины и средствами цифрового звукового вещания стандарта ТDAB проанализированы диапазоны рабочих частот РЭС радиотехнологии LTE с иелью определения полос частот совместного использования как общими, так и спечиальными пользователями. В определенных полосах частот проанализирован перечень средств военной техники воздушной телеметрии Вооруженных Сил Украины, которые используют и нуждаются в защите от непреднамеренных помех, создаваемых излучением РЭС технологии LTЕ. Определена в дальнейшем необходимость исследований усовериенствования модели множественной взаимодействия РЭС стандарта LTE и средств воздушной телеметрии ВСУ и средств изифрового звукового вещания стандарта T-DАВ на межсистемном уровне для определения худиих условий их взаимодействия.

Ключевые слова: электромагнитная совместимость, радиоэлектронные средства, общие пользователи, специальные пользователи, воздушная телеметрия, цифровое звуковое вещание, сети мобильной связи.

\section{ANALYSIS OF ELECTROMAGNETIC COMPATIBILITY BETWEEN RADIOELECTRONIC MEANS OF AIR TELEMETRY OF THE ARMED FORCES OF UKRAINE AND MEANS BY COMMON USERS IN FREQUENCY BAND IN THE 1427-1532 MHz}

\section{S. Makarov, O. Chekunova, A. Kovalchuk, S. Seleznov}

The analysis of normative-legal documents in the field of use of the radio frequency spectrum of Ukraine is carried out in the work. Analysis of the situation regarding the electromagnetic situation in the frequency bands, dedicated radio means shows that the main problem of restraining the development of modern high-tech public telecommunications systems is the lack of frequency resource in the most popular bands. The necessity of determining the possibility of joint use of means of air mobile and radio-satellite services of the Air Force of the Armed Forces of Ukraine with radio-electronic means of trunking communication of foreign production is substantiated. The introduction of digital mobile (mobile) networks in the new frequency bands requires experimental determination of permissible levels of unintentional interference from electronic electronic means of LTE radio technology to special users, which will determine the territorial and frequency restrictions on the location of LTE network elements. and predict electromagnetic compatibility between them. To assess and predict the electromagnetic compatibility and electromagnetic interaction of radio electronic means of LTE technology with air telemetry of the Armed Forces of Ukraine and digital audio broadcasting standard T-DAB analyzed the operating frequency ranges of electronic electronic radio equipment LTE for common use users. The list of air telemetry means of the Armed Forces of Ukraine, which use and need protection against unintentional interference created by the radiation of electronic means of LTE technology, which is the result of research, is analyzed in certain frequency bands. The need for further research to improve the model of multiple interaction of LTE radio-electronic means and radio-electronic means of air telemetry of the Armed Forces and digital audio broadcasting of the T-DAB standard at the intersystem level to determine the worst conditions of their interaction is determined.

Keywords: electromagnetic compatibility, radio electronic means, general users, special users, aerial telemetry, digital sound broadcasting, mobile networks. 